\title{
Aqueous metal-catalyzed living radical polymerization: highly active water-assisted catalysis
}

\author{
Makoto Ouchi, Hiroaki Yoda, Takaya Terashima and Mitsuo Sawamoto
}

Catalytic aqueous living radical polymerization was achieved through a ligand design for a ruthenium-based catalyst. A phenolic phosphine ligand $\left[\mathrm{PPh}_{2}(\mathrm{pPhOH})\right]$ was combined with a pentamethylcyclopentadienyl ( $\left.\mathrm{Cp}^{*}\right)$-based tetrameric ruthenium precursor, and the resulting complex showed a high catalytic activity for aqueous living radical polymerizations of hydrophilic methacrylates (for example, poly(ethylene glycol) methacrylate and 2-hydroxyethyl methacrylate) in conjunction with a chlorine initiator $\left[\mathrm{H}-(\mathrm{MMA})_{2}-\mathrm{Cl}\right.$. The catalytic system allowed very fast living polymerizations, block copolymerizations and syntheses of high-molecular-weight polymers $\left(D P_{n} \sim 1000\right)$ with narrow-molecular-weight distributions. Importantly, the activity was high enough to control the polymerization using a catalytic amount of the complex, even though the polymerizations were performed at low temperature $\left(40^{\circ} \mathrm{C}\right)$. Such advanced catalysis was achieved by not only simple hydrophilicity of the ligand but also by a water-assisted dynamic transformation from the original coordinatively saturated form $\left[C p * R u C l\left(P R_{3}\right)_{2} ; 18 e ; P_{3}=p h o s p h i n e\right]$ into an unsaturated and active form $\left[\mathrm{Cp}{ }^{*} \mathrm{RuCl}\left(\mathrm{PR}_{3}\right) ; 16 \mathrm{e}\right]$. Water molecule(s) may also coordinate for further stabilization as demonstrated by ${ }^{31} \mathrm{P}$ NMR analyses.

Polymer Journal (2012) 44, 51-58; doi:10.1038/pj.2011.59; published online 3 August 2011

Keywords: aqueous polymerization; block copolymerization; catalyst; living radical polymerization; phosphine; ruthenium

\section{INTRODUCTION}

Biological reactions occur in water with precise control and selectivity. Reactive sites recognize water-soluble substrates (or vice versa) via hydrogen bonding, hydrophobic and other weak interactions by which rigorously selective reactions proceed efficiently under mild conditions. On the other hand, chemists are generally not good at precise reaction control in aqueous systems because water is among the most 'polar' compounds and often promote side reactions and deactivation of substrates, intermediates and/or catalysts. This comparison indicates that one might achieve similar aqueous selectivity by mimicking biological reactions, particularly by utilizing the weak interactions found in water.

In sharp contrast to ionic polymerizations and related polar organic reactions, radical polymerization is inherently 'robust' against highly polar media and functionalities, and is thus generally immune to the 'poisonous' effect of water, because radical species are electronically neutral and are thus tolerant of polar groups. It is therefore common in industrial polymer production to conduct free radical polymerization in aqueous media, typically in emulsion and dispersion processes. Though these processes are technically established, precise radical polymerization in water is generally not possible.

Now that living radical polymerization has been demonstrated for a variety of monomers including functional derivatives, ${ }^{1-4}$ the precise control of radical polymerization in water is of interest not only for a wider range of functional and hydrophilic monomers but is also important from environmental viewpoints and for bioapplications. In particular, 'polymer bioconjugation ${ }^{5-7}$ or covalently linking synthetic polymers to biopolymers, has attracted attention in pharmaceutical and fine material applications. For these applications, fine control in 'aqueous' polymerization is required because most biomolecules are only soluble, properly structured and active in water.

Contemporary living radical polymerizations frequently involve transition metal-catalysts. ${ }^{1,8-14}$ Herein, a metal catalyst catalyzes the reversible activation of the carbon-halogen bond $(\sim \sim \mathrm{C}-\mathrm{X}$ $\leftrightarrow \sim \sim \mathrm{C} \bullet$; $\mathrm{X}=$ halogen) of an alkyl halide initiator and/or dormant polymer terminal in a one-electron redox step $\left(\mathrm{Mt}^{\mathrm{n}} \leftrightarrow \mathrm{XMt}^{\mathrm{n}+1}\right.$; $\mathrm{Mt}=$ transition metal such as $\mathrm{Ru}, \mathrm{Fe}, \mathrm{Ni}$ and $\mathrm{Cu}$ ), to generate a growth-active radical intermediate at a low concentration and thereby suppress bimolecular termination and other side reactions (Scheme 1). With high initiation efficiency and precise control, the metal-catalyzed systems are superior to other living radical polymerizations in the synthesis of well-defined architectures (for example, block copolymers) and hybridization/conjugation with other (bio)molecules.

On the other hand, the metal catalysts are usually sensitive to polar functionalities that often induce unfavorable interactions and thus suffer from a limitation in applicable monomers and solvents and from the contamination of resultant polymers with residual catalyst. 

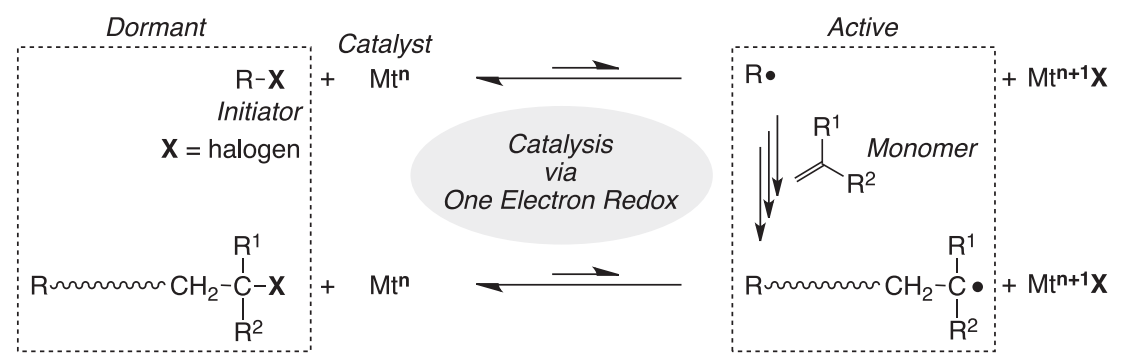

Scheme 1 Metal-catalyzed living radical polymerization.

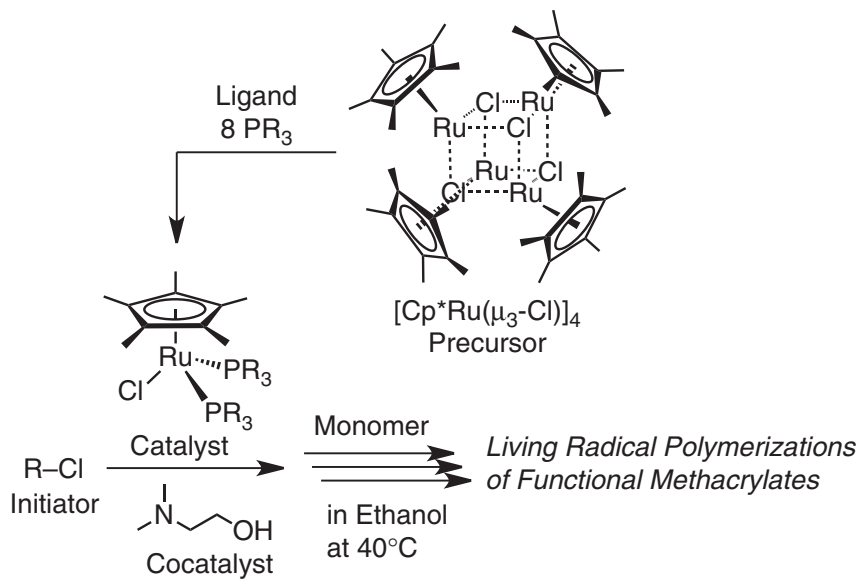

Scheme 2 Pentamethylcyclopentadienyl $\left(\mathrm{Cp}^{*}\right)$-based ruthenium catalyst for ethanol-mediated living radical polymerization.

It is thus increasingly important to develop transition metal catalysts that are robust with respect to polar groups, soluble in water and active enough to allow the extreme reduction of catalyst does. The perfect system then calls for fine reaction control in water to allow for hydrophilic monomers, a 'catalytic' amount of the catalyst and ready removal of its residues from the products. To our knowledge, however, truly aqueous catalysis is thus far unknown for living radical polymerization, ${ }^{15}$ and most 'aqueous' systems require a relatively high amount of catalyst $\left([\text { catalyst }]_{0} /[\text { initiator }]_{0} \sim 1\right)$ for fine control. ${ }^{16-20}$ This is likely due to the poor solubility of the metal complexes in water and their high sensitivity to interactions with water.

We have recently found that pentamethylcyclopentadienyl $\left(\mathrm{Cp}^{\star}\right)$ ruthenium complexes $\left[\mathrm{Cp}^{\star} \mathrm{Ru}(\mathrm{Cl}) \mathrm{L}_{2}: \mathrm{L}=\right.$ phosphine], prepared in situ from a tetrameric precursor $\left(\left[\mathrm{Cp}^{\star} \mathrm{Ru}\left(\mu_{3}-\mathrm{Cl}\right)\right]_{4}\right)$, are active, robust and universal catalysts for living radical polymerization in ethanol (EtOH) (Scheme 2). ${ }^{21}$ The ligand/co-catalyst combination of tri- $m$-tolylphosphine $\left[\mathrm{P}(m \mathrm{Tol})_{3} ; m \mathrm{Tol}=m-\mathrm{MeC}_{6} \mathrm{H}_{4}\right]$ and a hydrophilic amine [2-dimethylamino-1-ethanol: $\mathrm{Me}_{2} \mathrm{~N}\left(\mathrm{CH}_{2}\right)_{2} \mathrm{OH}$ ] supported fast-living radical polymerizations and fine molecular weight control $\left(M_{\mathrm{w}} / M_{\mathrm{n}}\right.$ $<1.2)$ for a variety of methacrylates. This catalysis is in fact tolerant of polar groups, giving well-defined homopolymers and random or block copolymers of functional monomers. It is proposed that an essential factor for the improved catalytic performance is the dynamic transformation of $\mathrm{Cp}^{\star} \mathrm{RuClP}(m \mathrm{Tol})_{3}$ (a 16e unsaturated 'active' complex) from $\mathrm{Cp}^{\star} \mathrm{RuCl}\left[\mathrm{P}(m \mathrm{Tol})_{3}\right]_{2}$ (an 18e pre-catalyst) in the alcoholic medium, which is believed to promote catalysis.

The high catalytic activity of the $\mathrm{Cp}^{\star} \mathrm{Ru}$ system in EtOH encouraged investigations of similarly active and efficient catalysis in water in which the solvent molecule may not only be non-interfering but may also indeed positively activate the catalyst. In fact, our preliminary results indicate enhancement of the $\mathrm{RuCp}^{*}$ catalytic cycle by the addition of a small amount of water into the EtOH solvent, and in situ ${ }^{31} \mathrm{P}$ NMR analysis showed the labile and dynamic coordination of the Ru center by the added water. These observations imply that, for these catalysts, water is not only a benign solvent but also an activator as well.

The present work attempts to direct controlled polymerization from 'in the presence of water' to 'in pure water'. Ligation of $\mathrm{PPh}_{2}(p \mathrm{PhOH})$ to the $\left[\mathrm{Cp}^{\star} \mathrm{Ru}\left(\mu_{3}-\mathrm{Cl}\right)\right]_{4}$ precursor permitted aqueous living radical polymerizations of hydrophilic methacrylates. The catalytic activity was very high, allowing the following features: very fast living polymerization; chain extension or block copolymerization via sequential in situ monomer addition; the reduction of catalyst concentration without any loss of reaction control; the synthesis of high-molecular-weight polymers with narrow-molecular-weight distributions (MWDs); and fine control of the polymerization of 2-hydroxyethyl methacrylate (HEMA) in water without forming an insoluble product or a gel.

\section{EXPERIMENTAL PROCEDURE}

\section{Materials}

Poly(ethylene glycol) methacrylate (PEGMA) $\left[\mathrm{CH}_{2}=\mathrm{CMeCO}_{2}\left(\mathrm{CH}_{2} \mathrm{CH}_{2} \mathrm{O}\right)_{n} \mathrm{Me}\right.$; $\mathrm{Me}=\mathrm{CH}_{3} ; n=8.5$ on average] (Aldrich, St Louis, MO, USA) was purified by passage through an inhibitor removal column (Aldrich) and subsequently degassed by three vacuum-argon-sparging cycles before use. HEMA (Aldrich; $>99 \%$ ) was distilled under reduced pressure before use. All ligands and ruthenium complexes were used as received without further purification and handled in a glovebox (MBraun Labmaster 130, M. Braun Inertgas-Systeme $\mathrm{GmbH}$, Garching, Germany) under a moisture- and oxygen-free argon atmosphere $\left(\mathrm{H}_{2} \mathrm{O}<1\right.$ p.p.m.; $\mathrm{O}_{2}<1$ p.p.m.): Tri- $m$-tolylphosphine (Sterem, Newburyport, MA, USA; > 98\%), (4-hydroxyphenyl)diphenylphosphine (Aldrich; 98\%), tris(hydroxymethyl)phosphine (Strem; > 85\%), tetrakis(hydroxymethyl) phosphonium chloride (Aldrich; $80 \%$ solution in water), formaldehyde (Aldrich, 37\% solution in water), hexamethylenetetramine (Aldrich; >99.5\%), ruthenium(III) chloride hydrate (Wako Chemicals, Osaka, Japan; >99.9\%), 1,2,3,4,5-pentamethylcyclopentadiene (Strem; 98\%) and lithium triethylhydridoborate (Aldrich; $1.0 \mathrm{~m}$ solution in tetrahydrofuran). The hydrophilic phosphine ligand, 1,3,5-triaza-7-phosphaadamantane, was prepared according to the literature. ${ }^{22}$ The tetramer precursor ruthenium complex $\left[\mathrm{Cp}{ }^{\star} \mathrm{Ru}\left(\mu_{3}-\mathrm{Cl}\right)\right]_{4}{ }^{23}$ and the chlorine initiator $\left[\mathrm{H}-(\mathrm{MMA})_{2}-\mathrm{Cl}\right]^{24}$ were also prepared according to published procedures. Toluene (Kishida Kagaku, Osaka, Japan; purity >99\%) was dried and purified by passing through purification columns (Solvent Dispensing System, SG Water USA, NH, USA; Glass Contour) and sparged with dry nitrogen for more than $15 \mathrm{~min}$ immediately before use. Ethanol (Wako Chemicals; dehydrated; 99.5\%), water (Wako Chemicals; distilled), and buffer solutions (TCI, Tokyo, Japan) were bubbled with dry nitrogen for more than $15 \mathrm{~min}$ immediately before use.

\section{Polymerization procedures}

Polymerization was carried out by the syringe technique under dry argon in baked glass tubes equipped with a three-way stopcock or in sealed glass vials. A typical procedure for the polymerization of PEGMA with $\mathrm{H}-(\mathrm{MMA})_{2}-\mathrm{Cl} /$ $\left[\mathrm{Cp}{ }^{*} \mathrm{Ru}\left(\mu_{3}-\mathrm{Cl}\right)\right]_{4} / \mathrm{PPh}_{2}(p \mathrm{PhOH})$ is given. A $50-\mathrm{ml}$ round-bottom flask was 
charged with $\left[\mathrm{Cp}{ }^{\star} \mathrm{Ru}\left(\mu_{3}-\mathrm{Cl}\right)\right]_{4}(4.3 \mathrm{mg}, 0.008 \mathrm{mmol}), \mathrm{PPh}_{2}(p \mathrm{PhOH})(9.7 \mathrm{mg}$, $0.032 \mathrm{mmol})$, toluene $(4 \mathrm{ml})$ and $\mathrm{EtOH}(1 \mathrm{ml})$. The solution was stirred at $60^{\circ} \mathrm{C}$ until the color changed from black-brown to red-brown (30 min). After cooling the flask to room temperature, the solution was evaporated and dried for $2 \mathrm{~h}$ at room temperature. After filling the flask with dry argon, PEGMA $(1.76 \mathrm{ml}$, $4.0 \mathrm{mM})$, buffer solution $(6.15 \mathrm{ml})$ and a solution of $\mathrm{H}-(\mathrm{MMA})_{2}-\mathrm{Cl}(0.091 \mathrm{ml}$, $437.4 \mathrm{~mm}$ in $\mathrm{EtOH}, 0.40 \mathrm{mmol}$ ) were sequentially added under dry argon at $0{ }^{\circ} \mathrm{C}$, so that the total volume of the reaction mixture was $8.0 \mathrm{ml}$. Immediately after mixing, aliquots $(0.50-1.0 \mathrm{ml}$ each) of the solution were injected into glass tubes that were then sealed (except when a stopcock was used) and placed in an oil bath kept at a desired temperature. At predetermined intervals, the polymerization was terminated by cooling the reaction mixtures to $-78^{\circ} \mathrm{C}$. Monomer conversion was determined from the ${ }^{1} \mathrm{H}$ NMR spectrum of the solution aliquot. The quenched reaction solutions were evaporated to dryness and the products were subsequently dried overnight under vacuum at room temperature.

\section{Measurements}

$M_{\mathrm{n}}$ and $M_{\mathrm{w}} / M_{\mathrm{n}}$ of the polymers were measured by size-exclusion chromatography (SEC) at $40{ }^{\circ} \mathrm{C}$ in dimethylformamide containing $10 \mathrm{mM} \mathrm{LiBr}$ as an eluent on three polystyrene-gel columns (Shodex KF-805L, Shodex, Tokyo,

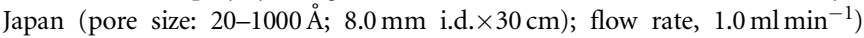
connected to a Jasco PU-2080 precision pump, a Jasco RI-2031 refractive-index detector and a Jasco UV-2075 ultraviolet detector (Jasco, Hachioji, Tokyo, Japan). The columns were calibrated against 13 standard poly(MMA) samples (Polymer Laboratories; $M_{\mathrm{n}}=630-1200000, M_{\mathrm{w}} / M_{\mathrm{n}}=1.06-1.22$ ) as well as the monomer. ${ }^{1} \mathrm{H}$ NMR and ${ }^{31} \mathrm{P}$ NMR spectra were measured at room temperature on a JEOL JNM-ECA500 spectrometer (JEOL, Akishima, Tokyo, Japan) operating at 500.16 and $202.47 \mathrm{MHz}$, respectively. For the ${ }^{31} \mathrm{P}$ NMR analyses, a capillary of $\left(\mathrm{C}_{2} \mathrm{H}_{5} \mathrm{O}\right)_{2} \mathrm{POH}$ solution $\left(50 \mathrm{~mm}\right.$ in toluene- $\left.d_{8}\right)$ was used as an internal chemical shift standard (12 p.p.m. for the phosphite).

\section{RESULTS AND DISCUSSION}

\section{Effects of water on the polymerization of PEGMA}

We recently reported that the EtOH-mediated catalytic system of $\left[\mathrm{Cp}{ }^{\star} \mathrm{Ru}\left(\mu_{3}-\mathrm{Cl}\right)\right]_{4} / \mathrm{P}(m \mathrm{Tol})_{3}$ in conjunction with an amino alcohol co-catalyst was active enough to control radical polymerization with a variety of functional methacrylates at $40{ }^{\circ} \mathrm{C} .{ }^{21}$ We first added water into the EtOH-mediated system to examine the effects of water on the catalysis. Polymerizations of PEGMA were then performed with $\left[\mathrm{Cp}{ }^{\star} \mathrm{Ru}\left(\mu_{3}-\mathrm{Cl}\right)\right]_{4} / \mathrm{P}(m \mathrm{Tol})_{3}$, coupled with $\left[\mathrm{H}-(\mathrm{MMA})_{2}-\mathrm{Cl}\right]$ as an initiator in mixture of $\mathrm{EtOH}$ and water at $40^{\circ} \mathrm{C}$ : [PEGMA] $]_{0} /$ $\left[\mathrm{H}-(\mathrm{MMA})_{2}-\mathrm{Cl}\right]_{0} /\left[\left[\mathrm{Cp}{ }^{*} \mathrm{Ru}\left(\mu_{3}-\mathrm{Cl}\right)\right]_{4}\right]_{0} /\left[\mathrm{P}(m \mathrm{Tol})_{3}\right]_{0}=500 / 5.0 / 0.5 / 4.0 \mathrm{mM}$ (100 mer conditions). In these experiments, no co-catalyst was used so that the effects of water could be tested without being convoluted by other factors. In pure and dry $\mathrm{EtOH}$, the polymerization was fairly controlled to give polymers of narrow MWDs $\left(M_{\mathrm{w}} / M_{\mathrm{n}}<1.12\right)$ but it was rather slow ( $144 \mathrm{~h}$ for $90 \%$ conversion). As water was added into the alcoholic solvent, the reactions were apparently accelerated. With $25 \mathrm{vol} \%$ water, very fast polymerization was observed ( $8 \mathrm{~h}$ for $96 \%$ conversion), although the MWDs were as good as in the pure EtOH system $\left(M_{\mathrm{w}} / M_{\mathrm{n}}<1.12\right)$. When water content was increased to $50 \mathrm{vol} \%$, a faster but less controlled polymerization occurred $\left(M_{\mathrm{w}} / M_{\mathrm{n}}\right.$ $\sim 1.3$ ), as the system became heterogeneous because of poor solubility of the ruthenium catalyst in the water-rich medium. Thus, addition of water within a certain range ( $<50 \mathrm{vol} \%$ relative to $\mathrm{EtOH})$ was found to be effective for acceleration, or the effective promotion of the catalytic cycle, maintaining both control and system homogeneity (Figure 1).

\section{Effects of water on ruthenium complexes}

Whenever a coordinatively saturated complex (for example, $\mathrm{Cp}^{\star} \mathrm{RuCl}\left(\mathrm{PR}_{3}\right)_{2} ; \mathrm{PR}_{3}=$ phosphine $)$ is used as a catalyst for redoxmediated living radical polymerization, it should be transformed into a coordinatively unsaturated form (for example, $\mathrm{Cp}{ }^{\star} \mathrm{RuCl}\left(\mathrm{PR}_{3}\right)$ ) so as to catalyze initiation and propagation. Thus, we examined the coordination behavior of the $\mathrm{Cp}^{\star} \mathrm{Ru}$ complex in the presence of water to help explain the accelerated polymerization.

The tetrameric precursor, $\left[\mathrm{Cp}^{*} \mathrm{Ru}\left(\mu_{3}-\mathrm{Cl}\right)\right]_{4}$, was heated with the ligand $\left[\mathrm{P}(m \mathrm{Tol})_{3}\right]$ in toluene to form the bisphosphine complex,
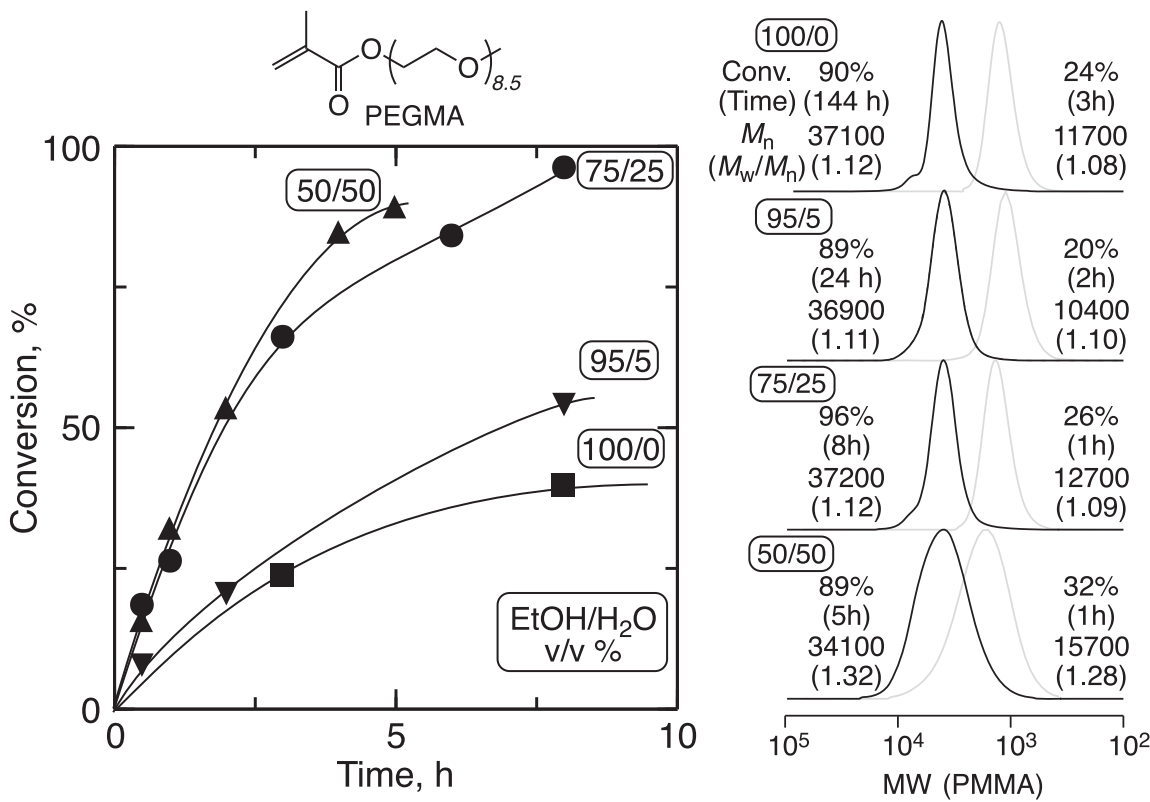

Figure 1 Effects of water on the polymerization of PEGMA with $\mathrm{Cp} * \mathrm{RuCl}\left[\mathrm{P}\left(m \mathrm{~mol}_{3}\right]_{2}\right.$ in conjunction with $\mathrm{H}-(\mathrm{MMA})_{2}-\mathrm{Cl}$ in ethanol $(\mathrm{EtOH}) / \mathrm{H}_{2} \mathrm{O}$ at $40{ }^{\circ} \mathrm{C}$ : $[\mathrm{PEGMA}]_{0}=0.5 \mathrm{M} ;\left[\mathrm{H}-(\mathrm{MMA})_{2}-\mathrm{Cl}\right]_{0}=5.0 \mathrm{~mm} ; \quad\left[\mathrm{Cp} * \mathrm{RuCl}\left[\mathrm{P}\left(m \mathrm{~mol}_{3}\right]_{2}\right]_{0}=2.0 \mathrm{~mm} . \quad \mathrm{EtOH} / \mathrm{H}_{2} \mathrm{O}(\mathrm{v} / \mathrm{v} \%)=100 / 0(\boldsymbol{\nabla}) ; 95 / 5(\boldsymbol{V}) ; 75 / 25(\boldsymbol{\bullet}) ; 50 / 50(\boldsymbol{\Delta})\right.$. The ruthenium complex was prepared via mixing of $\left[\mathrm{Cp} * \mathrm{Ru}\left(\mu_{3}-\mathrm{Cl}\right)\right]_{4}$ and $\mathrm{P}(m \mathrm{~mol})_{3}$ in toluene at $60{ }^{\circ} \mathrm{C}$ for $12 \mathrm{~h}$, followed by the evaporation before polymerization: $\left[\left[\mathrm{Cp} * \mathrm{Ru}\left(\mu_{3}-\mathrm{Cl}\right)\right]_{4}\right]=0.5 \mathrm{~mm} ;\left[\mathrm{P}(\mathrm{mTol})_{3}\right]=4.0 \mathrm{~mm}$. 


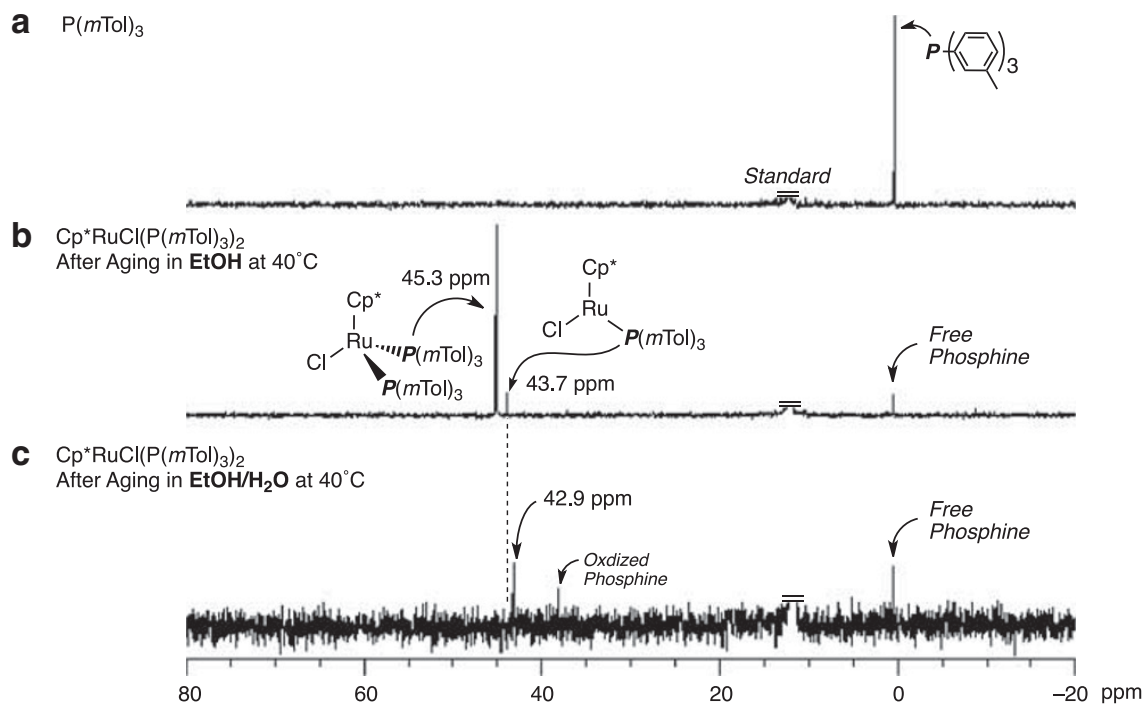

Figure $2{ }^{31} \mathrm{P} N M R$ (EtOH- $d_{6}$, r.t.) analyses of $\mathrm{Cp}{ }^{*} \mathrm{RuCl}\left[\mathrm{P}\left(m \mathrm{~mol}_{3}\right]_{2}\right.$ investigating the effects of water on the coordination sphere. (a) $\mathrm{P}(m \mathrm{~mol})_{3}$; (b) $\mathrm{Cp} * \mathrm{RuCl}\left[\mathrm{P}(m \mathrm{Tol})_{3}\right]_{2}$ after aging in $\mathrm{EtOH}$; (c) $\mathrm{Cp} * \mathrm{RuCl}\left[\mathrm{P}(m \mathrm{Tol})_{3}\right]_{2}$ after aging in $\mathrm{EtOH} / \mathrm{H}_{2} \mathrm{O}(60 / 40 \mathrm{v} / \mathrm{v} \%)$. The ruthenium complex was prepared via mixing of $\left[\mathrm{Cp}{ }^{*} \mathrm{Ru}\left(\mu_{3}-\mathrm{Cl}\right)\right]_{4}$ and $\mathrm{P}(m \mathrm{~mol})_{3}$ in toluene at $60^{\circ} \mathrm{C}$ for $12 \mathrm{~h}$, followed by the evaporation before the aging experiment in EtOH or EtOH/H $\mathrm{H}_{2} \mathrm{O}$. Sample concentrations for the ${ }^{31} \mathrm{P}$ NMR analyses were $\left[\mathrm{P}(m \mathrm{~mol})_{3}\right]=4.0 \mathrm{~mm}(\mathbf{a}) ;\left[\mathrm{Cp} * \mathrm{RuCl}\left[\mathrm{P}\left(m \mathrm{~mol}_{3}\right)_{2}\right]=4.0 \mathrm{~mm}(\mathbf{b}, \mathbf{c})\right.$.

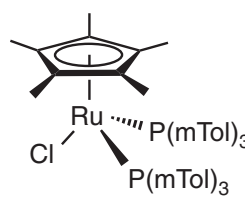

Saturated, $18 \mathrm{e}$

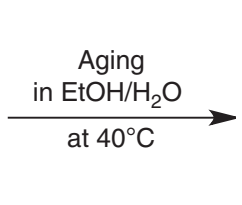

$$
\mathrm{H}-\mathrm{O}
$$$$
\text { H }
$$

\footnotetext{
Weak and Dynamic
}

Coordination of Water

Scheme 3 Proposed transformation of $\mathrm{Cp}{ }^{*} \mathrm{RuCl}\left[\mathrm{P}(m \mathrm{~mol})_{3}\right]_{2}$ via aging in $\mathrm{EtOH} / \mathrm{H}_{2} \mathrm{O}$ at $40{ }^{\circ} \mathrm{C}$.

$\mathrm{Cp}^{*} \mathrm{RuCl}\left[\mathrm{P}(m \mathrm{Tol})_{3}\right]_{2}$. The toluene was evaporated and the complex was aged in an EtOH/water solvent mixture $\left(60 / 40\right.$, v/v) at $40^{\circ} \mathrm{C}$ for $2 \mathrm{~h}$ before being evaporated and re-dissolved in $\mathrm{EtOH}-d_{6}$ for ${ }^{31} \mathrm{P} \mathrm{NMR}$ analysis. Aging in water-free pure EtOH was also examined for comparison. Figure 2 shows the ${ }^{31} \mathrm{P}$ NMR spectra of the phosphine ligand (Figure 2a) and the ruthenium complexes after aging in pure $\mathrm{EtOH}$ (Figure 2b) and in EtOH/water mixture (Figure 2c). For the complex aged in EtOH (Figure 2b), two small peaks were detected at 43.7 and 0.2 p.p.m., in addition to the main signal (45.3 p.p.m.) from the bisphosphine form. The small peak at 0.2 p.p.m. is at the same position as with the free phosphine (Figure $2 \mathrm{a}$ ), indicating that a portion of the phosphines on the originally bis-ligated complex is no longer coordinated. The other minor peak at 43.7 p.p.m. is therefore most likely indicative of a mono-ligated complex $\mathrm{Cp}^{\star} \mathrm{RuCl}\left[\mathrm{P}(m \mathrm{Tol})_{3}\right]$.

On the other hand, the 45.3-p.p.m. peak for the bis-ligated complex was completely absent for the sample aged in the EtOH/water mixture (Figure 2c). A new peak was instead observed upfield (42.9 p.p.m.), and the signal for the free phosphine (0 p.p.m.) was relatively intense. The new upfield peak is tentatively assigned to a complex carrying only one phosphine ligand. Because this peak is slightly, but noticeably, different in chemical shift from the corresponding higher-field peak for the EtOH-aged sample (43.7 vs 42.9 p.p.m.), water molecule(s) in the 'wet' EtOH might dynamically coordinate the vacant site of the mono-ligated unsaturated complex $\left(\mathrm{Cp}^{\star} \operatorname{RuCl}\left[\mathrm{P}(m \mathrm{Tol})_{3}\right]\right)$ for additional stabilization (Scheme 3 ). The labile ligation of water would facilitate the incipient generation of the unsaturated form, which is active in radical formation, in agreement with the observed accelerated polymerization in the presence of water.

\section{Aqueous living radical polymerization through ligand design}

Water addition was found to promote the catalytic cycle in metalcatalyzed living radical polymerization with $\left.\mathrm{Cp}^{\star} \mathrm{Ru}\left(\mu_{3}-\mathrm{Cl}\right)\right]_{4} /$ $\mathrm{P}(m \mathrm{Tol})_{3}$. However, the hydrophobicity of $\mathrm{P}(m \mathrm{Tol})_{3}$ incurred poorer polymerization control in the presence of an excessively large amount of water ( $>50 \mathrm{vol} \%$ relative to EtOH) because of the poor solubility. Thus, our next efforts were directed in search of more hydrophilic phosphines that would promote fast and efficient, but controlled, catalysis in water.

Three hydrophilic phosphine ligands were used with the tetrameric ruthenium precursor $\left(\left[\mathrm{Cp}^{\star} \mathrm{Ru}\left(\mu_{3}-\mathrm{Cl}\right)\right]_{4}\right)$ in the aqueous polymerizations of PEGMA (Figure 3): (4-hydroxyphenyl)diphenylphosphine $\left[\mathrm{PPh}_{2}(p \mathrm{PhOH})\right] ;$ 1,3,5-triaza-7-phosphaadamantane; and tris(hydroxymethyl)phosphine. For in-situ ligation, an eightfold molar excess of these phosphines was mixed with $\left[\mathrm{Cp}^{\star} \mathrm{Ru}\left(\mu_{3}-\mathrm{Cl}\right)\right]_{4}$ in toluene or the mixed solvent with EtOH. The solvent and the aging time were changed to accomplish the coordination or to improve solubility of the formed complex for each ligand system. After aging for $2 \mathrm{~h}$, the 

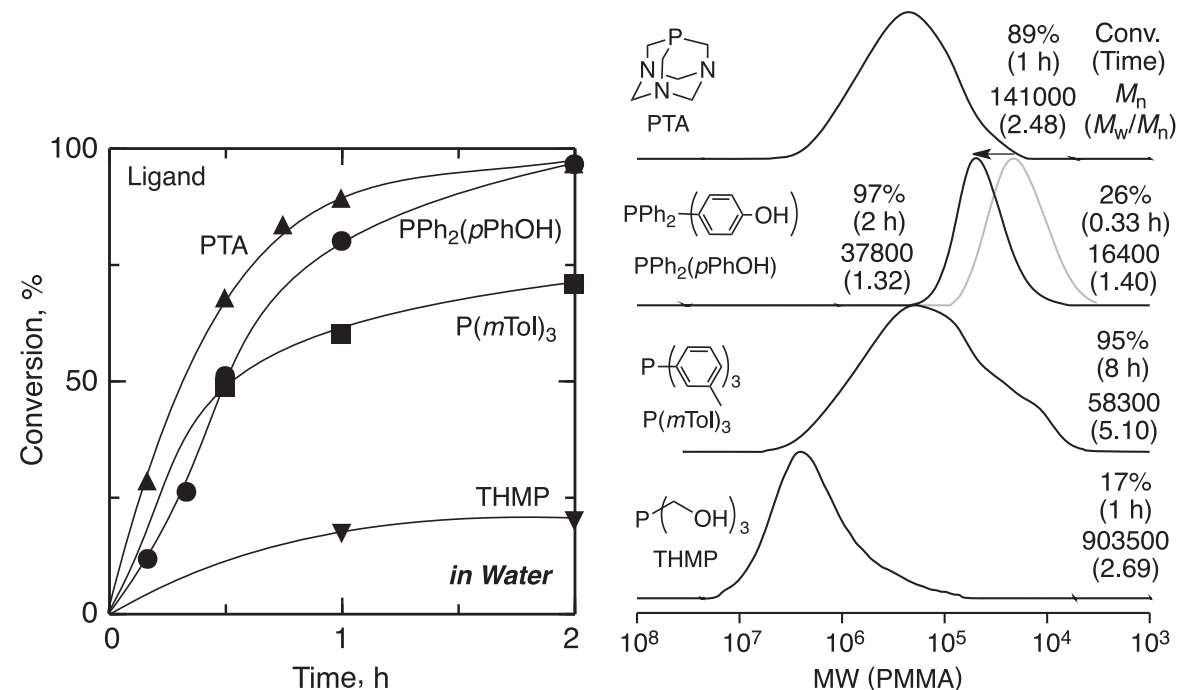

Figure 3 Effects of phosphine ligand on an aqueous polymerization of PEGMA with $\left[\mathrm{Cp}{ }^{*} \mathrm{Ru}\left(\mu_{3}-\mathrm{Cl}\right)\right]_{4}$ in conjunction with $\mathrm{H}-(\mathrm{MMA})_{2}-\mathrm{Cl}$ in $\mathrm{H}_{2} \mathrm{O}(\mathrm{pH} 8.0)$ at $40^{\circ} \mathrm{C}:[\mathrm{PEGMA}]_{0}=0.5 \mathrm{M} ;\left[\mathrm{H}-(\mathrm{MMA})_{2}-\mathrm{Cl}\right]_{0}=5.0 \mathrm{~mm}$; [ruthenium complex $]_{0}=2.0 \mathrm{~mm}$. The ruthenium complexes were prepared before the polymerization via mixing of $\left[\mathrm{Cp}{ }^{*} \mathrm{Ru}\left(\mu_{3}-\mathrm{Cl}\right)\right]_{4}$ with the phosphine ligand in solution at $\left.60^{\circ} \mathrm{C}:\left[\mathrm{Cp}{ }^{*} \mathrm{Ru}\left(\mu_{3}-\mathrm{Cl}\right)\right]_{4}\right]=0.5 \mathrm{~mm}$; [phosphine]=4.0 mM. The solvent and the aging time were changed according to the requirements of each ligand: toluene, $12 \mathrm{~h}$ [1,3,5-triaza-7-phosphaadamantane and $\left.\mathrm{P}(\mathrm{mTol})_{3}\right]$; toluene/EtOH, 30 min 4-(hydroxyphenyl)diphenylphosphine ([PPh $(p P h O H)]) ; E t O H, 12$ h (tris(hydroxymethyl)phosphine) (THMP). Phosphine: $\mathrm{PTA}(\mathbf{\Delta}) ; \mathrm{PPh} 2(p \mathrm{PhOH})(\bullet)$ $\operatorname{THMP}(\mathbf{\nabla}) ; \mathrm{P}\left(m \mathrm{TOI}_{3}(\mathbf{\square})\right.$.
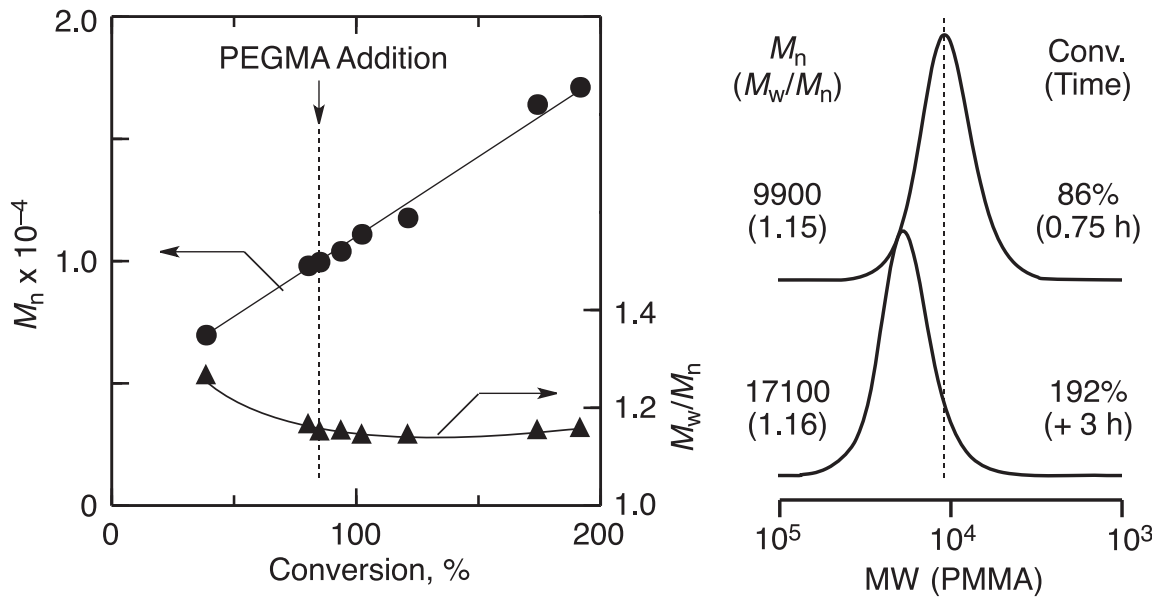

Figure 4 Monomer-addition experiment of the aqueous living radical polymerization of PEGMA with $\mathrm{H}-(\mathrm{MMA})_{2}-\mathrm{Cl} /\left[\mathrm{Cp} * \mathrm{Ru}\left(\mu_{3}-\mathrm{Cl}\right)\right]_{4} / \mathrm{PPh}_{2}(p \mathrm{PhOH})$ in $\mathrm{H}_{2} \mathrm{O}(\mathrm{pH}$ 8.0) at $40{ }^{\circ} \mathrm{C}:[\mathrm{PEGMA}]_{0}=500 \mathrm{~mm} ;\left[\mathrm{H}-(\mathrm{MMA})_{2}-\mathrm{Cl}\right]_{0}=20 \mathrm{~mm} ;\left[\left[\mathrm{Cp} * \mathrm{Ru}\left(\mu_{3}-\mathrm{Cl}\right)\right]_{4}\right]_{0}=0.5 \mathrm{~mm} ;\left[\mathrm{PPh}_{2}(p \mathrm{PhOH})\right]_{0}=4.0 \mathrm{~mm}$; $[\mathrm{PEGMA}]_{\text {add }}=500 \mathrm{~mm}$. The ruthenium complex was prepared before the polymerization via mixing of $\left[\mathrm{Cp}{ }^{*} \mathrm{Ru}\left(\mu_{3}-\mathrm{Cl}\right)\right]_{4}$ with $\mathrm{PPh}_{2}(p \mathrm{PhOH})$ in toluene/EtOH at $60{ }^{\circ} \mathrm{C}$ for $30 \mathrm{~min}$, and used directly for the polymerization after evaporation of the solvent.

solution was evaporated and the as-obtained complex was directly used for the polymerization in aqueous buffer solution $\left(\mathrm{H}_{3} \mathrm{BO}_{3}-\mathrm{KCl}-\right.$ $\mathrm{NaOH})$ at $\mathrm{pH} 8$, in which the concentrations of components were adjusted to $[\mathrm{PEGMA}]_{0} /\left[\mathrm{H}-(\mathrm{MMA})_{2}-\mathrm{Cl}\right]_{0} /\left[\left[\mathrm{Cp}{ }^{*} \mathrm{Ru}\left(\mu_{3}-\mathrm{Cl}\right)\right]_{4}\right]_{0} /$ $[\text { ligand }]_{0}=500 / 5.0 / 0.5 / 4.0 \mathrm{~mm}$ (the so-called 100 -mer condition). In contrast to the experiment using $\left[\mathrm{P}(m \mathrm{Tol})_{3}\right]$, the polymerization solutions were almost homogeneous with the three phosphines.

Among the three ligands, only the aromatic phosphine, $\mathrm{PPh}_{2}(p \mathrm{PhOH})$, induced a fast and controlled polymerization $(97 \%$ conversion in $2 \mathrm{~h}$ ): Gel permeation chromatography curves shifted to higher molecular weight with conversion while keeping narrow MWDs $\left(M_{\mathrm{w}} / M_{\mathrm{n}}<1.40\right)$. On the other hand, the polymerizations with aliphatic 1,3,5-triaza-7-phosphaadamantane or tris(hydroxy- methyl)phosphine were not controlled and gave higher molecular weights and broader MWDs.

\section{Evidence for living polymerization in water}

To examine the 'living' nature of the polymerization with $\mathrm{PPh}_{2}(p \mathrm{PhOH})$, a monomer-addition experiment was performed (Figure 4). PEGMA was first polymerized in water ( $\mathrm{pH} 8$ buffer) with $\left[\mathrm{Cp}{ }^{\star} \mathrm{Ru}\left(\mu_{3}-\mathrm{Cl}\right)\right]_{4} / \mathrm{PPh}_{2}(p \mathrm{PhOH})$, in conjunction with $\mathrm{H}-(\mathrm{MMA})_{2}-\mathrm{Cl}$ as an initiator: [PEGMA $]_{0} /\left[\mathrm{H}-(\mathrm{MMA})_{2}-\mathrm{Cl}\right]_{0} /\left[\left[\mathrm{Cp}{ }^{\star} \mathrm{Ru}\left(\mu_{3}-\mathrm{Cl}\right)\right]_{4}\right]_{0} /$ $[\text { ligand }]_{0}=500 / 20 / 0.5 / 4.0 \mathrm{~mm} ; 25 \mathrm{mer}$ condition. When the monomer conversion reached $86 \%$ conversion ( $45 \mathrm{~min}$ ), a fresh feed of PEGMA was added to the reaction mixture. A smooth and near quantitative polymerization ensued ( $96 \%$ in an additional $3 \mathrm{~h}$ ), and the linear 
$M_{\mathrm{n}}$-conversion plots and the narrow MWDs $\left(M_{\mathrm{w}} / M_{\mathrm{n}} \sim 1.15\right)$ were consistent with living polymerization.

In this aqueous living radical polymerization, molecular weight could also be controlled by changing the $[\text { monomer }]_{0} /[\text { initiator }]_{0}$ feed ratio. Figure 5 shows SEC profiles of polymers obtained at ratios of 25 , 100,500 and 1000 . Here, the use of ratios of 25 and 100 is same for

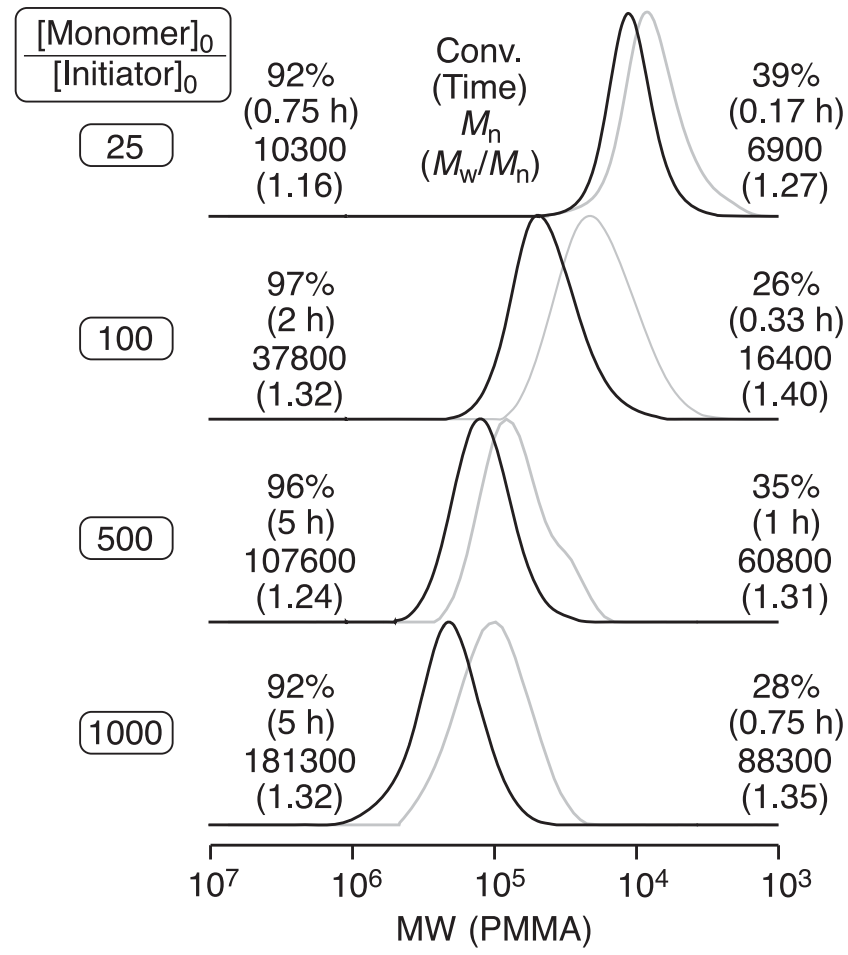

Figure 5 Molecular weight control by modification of the ratio of monomer to initiator $\left([\mathrm{PEGMA}]_{0} /\left[\mathrm{H}-(\mathrm{MMA})_{2}-\mathrm{Cl}\right]_{0}\right)$ in the aqueous living radical polymerization of PEGMA with $\mathrm{H}-(\mathrm{MMA})_{2}-\mathrm{Cl} /\left[\mathrm{Cp} * \mathrm{Ru}\left(\mu_{3}-\mathrm{Cl}\right)\right]_{4} / \mathrm{PPh}_{2}(p \mathrm{PhOH})$ in $\mathrm{H}_{2} \mathrm{O}(\mathrm{pH} 8.0)$ at $40^{\circ} \mathrm{C}$. [PEGMA $]_{0} /\left[\mathrm{H}-(\mathrm{MMA})_{2}-\mathrm{Cl}\right]_{0} /\left[\left[\mathrm{Cp} * \mathrm{Ru}\left(\mu_{3}-\mathrm{Cl}\right)\right]_{4}\right]_{0} /$ $\left[\mathrm{PPh}_{2}(\mathrm{pPhOH})\right]_{0}=500 / 20 / 0.5 / 4.0$ (25 mer); 500/5.0/0.5/4.0 (100 mer); 300/0.6/0.05/0.4 mm (500 mer); 300/0.3/0.05/0.4 (1000mer). See Figure 4 for preparation of the ruthenium complex. studying the ligand effect (Figure 3 ) and that of the reduction of catalyst (Figure 6), respectively. Under all these conditions, molecular weights were fairly well controlled and increased according to the feed ratio (as the SEC molecular weights are calibrated with the polymethylmethacrylate standards, the observed molecular weights cannot be compared with the calculated values based on the monomer/ initiator feed ratio). Note that advanced catalysis (that is, the combination of fast polymerization, complete monomer consumption and a narrow MWD) was retained for a high $[\text { monomer }]_{0} /[\text { initiator }]_{0}$ ratio $(=1000)$ and without any co-catalyst.

\section{Reduction of catalyst dose}

The enhanced catalytic activity of the $\left[\mathrm{Cp}{ }^{\star} \mathrm{Ru}\left(\mu_{3}-\mathrm{Cl}\right)\right]_{4} / \mathrm{PPh}_{2}(p \mathrm{PhOH})$ system in water encouraged us to reduce the amount of catalyst added because metal residue in products is unfavorable, especially in some bioapplications. For example, the complex concentration was reduced from $2.0 \mathrm{~mm}$ in the standard system (Figures 4 and 5) to 1.0, 0.40 and $0.20 \mathrm{~mm}$ in the $25-$ mer synthesis at $[\mathrm{PEGMA}]_{0} /\left[\mathrm{H}-(\mathrm{MMA})_{2}-\mathrm{Cl}\right]_{0}=500 /$ $25 \mathrm{~mm}$ (Figure 6). The polymerization decelerated with decreased catalyst amount, as expected, but the catalytic activity was high enough to reach near complete monomer consumption within several hours. Polymer molecular weight increased with conversion, while narrow MWDs were maintained, although the lowest catalyst dose $(0.2 \mathrm{~mm})$ in fact resulted in broader distributions. A catalyst load as low as $0.4 \mathrm{~mm}$ was sufficient to catalyze living radical polymerization $\left(M_{\mathrm{w}} / M_{\mathrm{n}}=1.29\right.$ at $94 \%$ conversion), and in this particular case, the as-obtained polymer solution was almost colorless. Under these conditions, the initial catalyst dose was $1 / 50$ of the initiator by molar ratio and 170 p.p.m. of the monomer by weight, indicating a much higher catalytic activity relative to previously known aqueous systems with ruthenium catalysts.

\section{Aqueous polymerization of HEMA and sodium methacrylate}

The $\left[\mathrm{Cp}^{*} \mathrm{Ru}\left(\mu_{3}-\mathrm{Cl}\right)\right]_{4} / \mathrm{PPh}_{2}(p \mathrm{PhOH})$ system was applicable for other hydrophilic monomers such as HEMA. It is considered difficult to synthesize linear poly(HEMA) via radical polymerization in water, where crosslinking via transesterification among the pendent hydroxyl groups often leads to crosslinked polymers. ${ }^{25}$ This rendered previous controlled radical polymerizations of HEMA, reliable only in alcohols or mixed solvents with water. ${ }^{26,27}$ In contrast, the catalytic system with $\mathrm{PPh}_{2}(p \mathrm{PhOH})$ allowed a controlled aqueous polymerization of HEMA
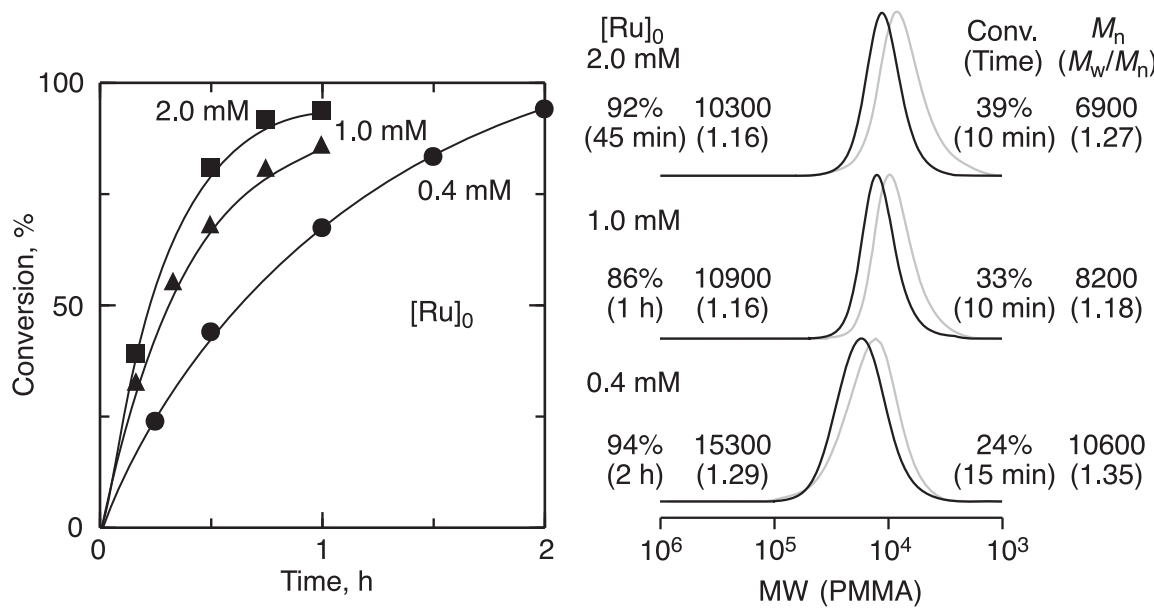

Figure 6 Reduction of catalyst dose in the aqueous living radical polymerization of PEGMA with $\mathrm{H}-(\mathrm{MMA})_{2}-\mathrm{Cl} /\left[\mathrm{Cp} * \mathrm{Ru}^{*}\left(\mu_{3}-\mathrm{Cl}\right)\right]_{4} / \mathrm{PPh} \mathrm{PhPOH}_{2}\left(p \mathrm{Pn} \mathrm{H}_{2} \mathrm{O}(\mathrm{pH}\right.$ 8.0) at $40^{\circ} \mathrm{C}$. $[\mathrm{PEGMA}]_{0}=500 \mathrm{~mm}$; $\left[\mathrm{H}-(\mathrm{MMA})_{2}-\mathrm{Cl}\right]_{0}=20 \mathrm{~mm}$; $\left[\left[\mathrm{Cp}^{*} \mathrm{Ru}\left(\mu_{3}-\mathrm{Cl}\right)\right]_{4}\right]_{0}=0.5,0.25$ or $0.1 \mathrm{~mm}$; $\left[\mathrm{PPh}_{2}(p \mathrm{PhOH})\right]_{0}=4.0,2.0$ or $0.8 \mathrm{~mm}$. Catalyst concentration: $2.0 \mathrm{~mm}(\bullet) ; 1.0 \mathrm{~mm}(\mathbf{\Lambda}) ; 0.4 \mathrm{~mm}(\mathbf{\square})$. See Figure 4 for preparation of the ruthenium complex. 

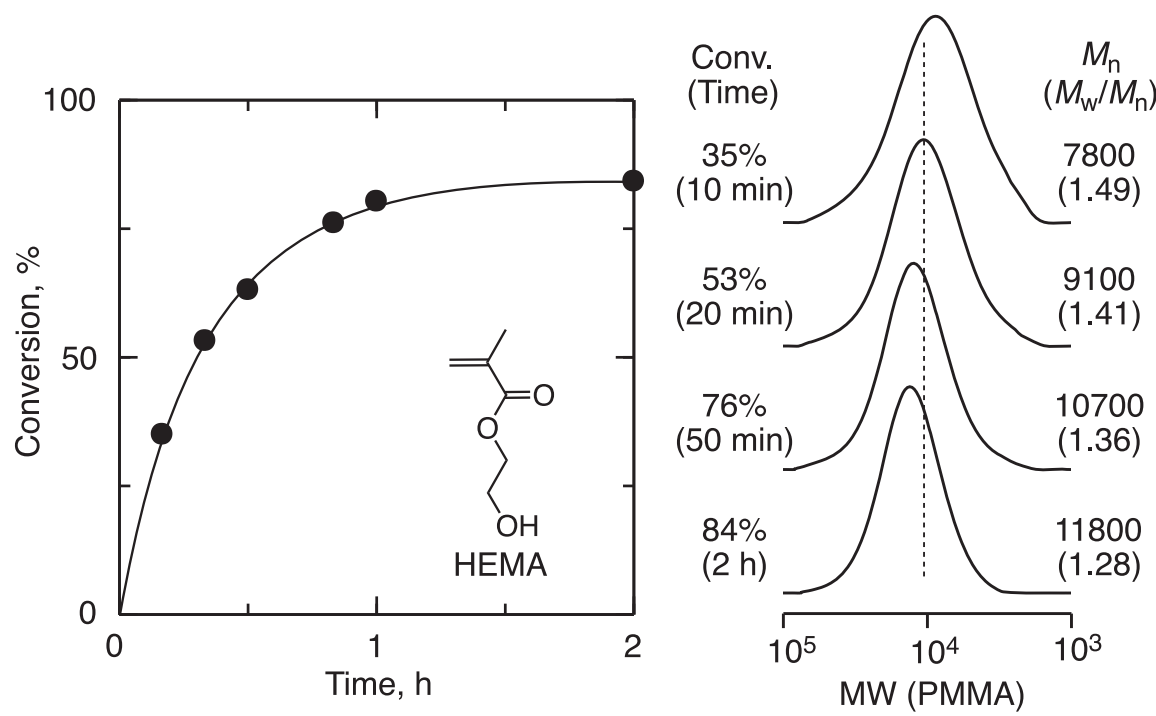

Figure 7 Aqueous polymerization of $\mathrm{HEMA}$ with $\mathrm{H}-(\mathrm{MMA})_{2}-\mathrm{Cl} /\left[\mathrm{Cp} * \mathrm{Ru}\left(\mu_{3}-\mathrm{Cl}\right)\right]_{4} / \mathrm{PPh}_{2}(p \mathrm{PhOH})$ in $\mathrm{H}_{2} \mathrm{O}(\mathrm{pH} 8.0)$ at $40^{\circ} \mathrm{C}$. $[\mathrm{HEMA}]_{0}=2.0 \mathrm{M}$; $\left[\mathrm{H}-(\mathrm{MMA})_{2}-\right.$ $\mathrm{Cl}]_{0}=40 \mathrm{~mm} ;\left[\left[\mathrm{Cp} * \mathrm{Ru}\left(\mu_{3}-\mathrm{Cl}\right)\right]_{4}\right]_{0}=0.5 \mathrm{~mm} ;\left[\mathrm{PPh}_{2}(p \mathrm{PhOH})\right]_{0}=4.0 \mathrm{~mm}$. See Figure 4 for preparation of the ruthenium complex.

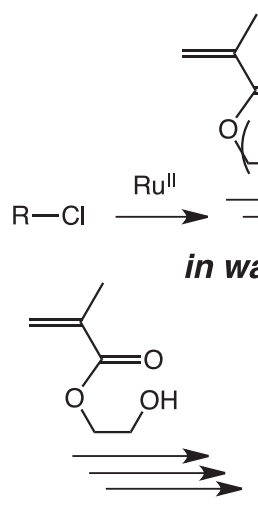

in water

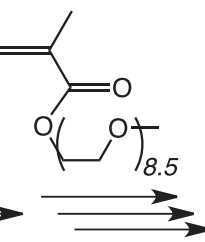

in water<smiles>COCCOC(C)(C)C(C)(C)C(C)(C)C</smiles>

Poly(PEGMA)

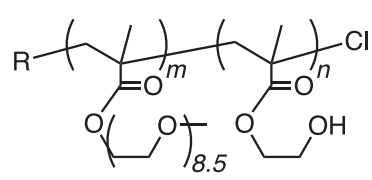

Poly(PEGMA-block-HEMA)

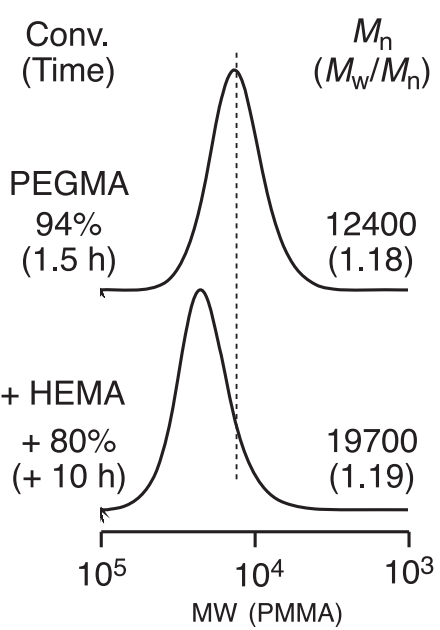

Figure 8 Block copolymerization of PEGMA and HEMA with $\mathrm{H}-(\mathrm{MMA})_{2}-\mathrm{Cl} /\left[\mathrm{Cp} * \mathrm{Ru}\left(\mu_{3}-\mathrm{Cl}\right)\right]_{4} / \mathrm{PPh}_{2}(p \mathrm{PhOH})$ in $\mathrm{H}_{2} \mathrm{O}(\mathrm{pH} 8.0)$ at $40^{\circ} \mathrm{C}$. $[\mathrm{PEGMA}]_{0}=0.5 \mathrm{~m}$; $\left[\mathrm{H}-(\mathrm{MMA})_{2}-\mathrm{Cl}\right]_{0}=20 \mathrm{~mm} ;\left[\left[\mathrm{Cp} * \mathrm{Ru}\left(\mu_{3}-\mathrm{Cl}\right)\right]_{4}\right]_{0}=0.5 \mathrm{~mm} ;\left[\mathrm{PPh}_{2}(\mathrm{pPhOH})\right]_{0}=4.0 \mathrm{~mm}$; $[\mathrm{HEMA}]_{\text {add }}=1.0 \mathrm{~m}$. See Figure 4 for preparation of the ruthenium complex.

at $40{ }^{\circ} \mathrm{C}$ in water (buffered; $\left.\mathrm{pH} 8.0\right)$ : $[\mathrm{HEMA}]_{0} /\left[\mathrm{H}-(\mathrm{MMA})_{2}-\mathrm{Cl}\right]_{0} /$ $\left.\left[\mathrm{Cp}^{\star} \mathrm{Ru}\left(\mu_{3}-\mathrm{Cl}\right)\right]_{4}\right]_{0} /\left[\mathrm{PPh}_{2}(p \mathrm{PhOH})\right]_{0}=2000 / 40 / 0.5 / 4.0 \mathrm{~mm}$ (Figure 7). The polymerization proceeded smoothly, without insoluble or crosslinked products, and the polymers showed narrow MWDs (reaching $M_{\mathrm{w}} / M_{\mathrm{n}}=1.28$ at a higher conversion). The $M_{\mathrm{n}}$ was controlled by the monomer to initiator feed ratio. To our knowledge, this is the first report of the controlled aqueous polymerization control for of HEMA. It is not clear whether the control over radical propagation is related to the homogeneous polymerization without forming a gel. Beside the controllability of polymerization, the use of buffer $\mathrm{pH} 8 \mathrm{might}$ contribute as well. This is now under investigation.

Polymerization of sodium methacrylate was also studied with the same aqueous catalytic system (Supplementary Information, Figure S1). Even with the hydrophilic ligand, the ruthenium complex was insoluble in water containing sodium methacrylate, and $25 \mathrm{vol} \%$ of $\mathrm{EtOH}$ was required for homogeneous solutions. Monomer conversion reached $82 \%$ in $72 \mathrm{~h}$, at which stage, however, a part of polymeric product began to precipitate. SEC analysis showed that the polymerization was somewhat controlled: polymer molecular weight increased with conversion, though a small additional peak was observed in the lower molecular weight region. Further investigations of sodium methacrylate polymerization are currently under way.

\section{Block and random copolymerizations}

With precise control achieved for homopolymerization in water with a catalytic amount of the ruthenium complex, block and random copolymerizations were attempted to demonstrate the system's versatility. When the aqueous living radical polymerization of PEGMA was nearly finished ( $94 \%$ conversion, $1.5 \mathrm{~h}$ ), neat HEMA was added (50 eq. relative to the initiator): $[\mathrm{PEGMA}]_{0} /\left[\mathrm{H}-(\mathrm{MMA})_{2}-\mathrm{Cl}\right]_{0} /\left[\left[\mathrm{Cp}^{*} \mathrm{Ru}\left(\mu_{3}\right.\right.\right.$ $\left.\mathrm{Cl})]_{4}\right]_{0} /[\text { ligand }]_{0} /[\mathrm{HEMA}]_{\text {add }}=500 / 20 / 0.5 / 4.0 / 1000 \mathrm{~mm}$ (Figure 8). The second monomer was smoothly consumed, proceeding to $80 \%$ conversion in $10 \mathrm{~h}$. The SEC curves before and after the HEMA addition showed a clear peak shift without any shoulder or tailing. 
The poly(PEGMA) chains in the first stage, thus, grew nearly quantitatively with HEMA, free from side reactions, to give block copolymers. Living random copolymerization of PEGMA and HEMA was also successful (Supplementary Information, Figure S2).

\section{Effects of $\mathrm{pH}$ on polymerization control}

For some aqueous reactions and polymerizations, $\mathrm{pH}$ adjustment is essential for precise control. In the ruthenium-catalyzed aqueous living radical polymerizations (see above), a pH 8.0 buffer with $\mathrm{H}_{3} \mathrm{BO}_{3}, \mathrm{KCl}$ and $\mathrm{NaOH}$ was used as the solvent. Other buffer solutions were also used for PEGMA: $\mathrm{KH}_{2} \mathrm{PO}_{4} / \mathrm{NaOH}$, $\mathrm{pH} 6.0 ; \mathrm{H}_{3} \mathrm{BO}_{3} / \mathrm{KCl} / \mathrm{NaOH}, \mathrm{pH}$ 9.6. Fast and quantitative polymerizations proceeded with these solutions; however, the polymers obtained were less controlled $\left(M_{\mathrm{w}} / M_{\mathrm{n}}>1.6\right)$ (Supplementary Information, Figure S3). As the ligand is phenolic, the solubility of the complex and the phosphine's coordination would be sensitive to $\mathrm{pH}$, leading to poor solubility of the catalyst at a lower $\mathrm{pH}$ and an unfavorable reaction of the phenoxy anion $\left(\mathrm{ArO}^{-}\right)$with $\mathrm{Ru}-\mathrm{Cl}$ to form $\mathrm{Ru}-\mathrm{OAr}$ at higher $\mathrm{pH}$. Further ligand design is underway in our group to allow aqueous living polymerization in a wide range of $\mathrm{pH}$ conditions.

\section{CONCLUSION}

This work demonstrates aqueous living radical polymerizations of PEGMA and HEMA achieved via ligand design in a ruthenium complex. The ruthenium complex, prepared in situ from $\left[\mathrm{Cp}^{\star} \mathrm{Ru}\left(\mu_{3}-\mathrm{Cl}\right)\right]_{4}$ and $\mathrm{PPh}_{2}(p \mathrm{PhOH})$, led to fast and complete living radical polymerization in water at a relatively low temperature $\left(40^{\circ} \mathrm{C}\right)$ and with a low ruthenium dose (1/50 relative to initiator, 170 p.p.m. relative to monomer), to give PEGMA-HEMA block copolymers and high MW polymers (DP > 1000) with narrow MWDs. Such advanced catalytic control is realized not only by a simple hydrophilicity of the ligand but also by a water-promoted catalytic cycle (as supported by ${ }^{31} \mathrm{P}$ NMR). Water likely induces a catalyst transformation via ligand elimination, from the original saturated form $\left[\mathrm{Cp}^{\star} \mathrm{RuCl}\left(\mathrm{PR}_{3}\right)_{2} ; 18 \mathrm{e}\right]$ into an unsaturated but active form $\left[\mathrm{Cp}^{\star} \mathrm{RuCl}\left(\mathrm{PR}_{3}\right) ; 16 \mathrm{e}\right]$ to which labile water molecule(s) may coordinate for further stabilization. This system opens the door to bioconjugation and other applications that require living polymerizations in water.

\section{ACKNOWLEDGEMENTS}

This research was partially supported by the Ministry of Education, Science, Sports and Culture of Japan through a Grant-in-Aid for Creative Science Research (18GS0209), by a Joint Development Research Program of the Korea Institute of Science and Technology, and by the Sumitomo Foundation.

1 Ouchi, M., Terashima, T. \& Sawamoto, M. Transition metal-catalyzed living radical polymerization: toward perfection in catalysis and precision polymer synthesis. Chem. Rev. 109, 4963-5050 (2009).
2 Hawker, C. J., Bosman, A. W. \& Harth, E. New polymer synthesis by nitroxide mediated living radical polymerizations. Chem. Rev. 101, 3661-3688 (2001).

3 Moad, G., Rizzardo, E. \& Thang, S. H. Radical addition-fragmentation chemistry in polymer synthesis. Polymer 49, 1079-1131 (2008).

4 Yamago, S. Precision polymer synthesis by degenerative transfer controlled/living radical polymerization using organotellurium, organostibine, and organobismuthine chain-transfer agents. Chem. Rev. 109, 5051-5068 (2009).

5 Heredia, K. L. \& Maynard, H. D. Synthesis of protein-polymer conjugates. Org. Biomol. Chem. 5, 45-53 (2007).

6 Nicolas, J., Mantovani, G. \& Haddleton, D. M. Living radical polymerization as a tool for the synthesis of polymer-protein/peptide bioconjugates. Macromol. Rapid. Comm. 28, 1083-1111 (2007).

7 Gauthier, M. A. \& Klok, H. A. Peptide/protein-polymer conjugates: synthetic strategies and design concepts. Chem. Commun. 2591-2611 (2008).

8 Kamigaito, M., Ando, T. \& Sawamoto, M. Metal-catalyzed living radical polymerization. Chem. Rev. 101, 3689-3745 (2001).

9 Kamigaito, M., Ando, T. \& Sawamoto, M. Metal-catalyzed living radical polymerization: discovery and developments. Chem. Rec. 4, 159-175 (2004).

10 Kamigaito, M. Recent developments in metal-catalyzed living radical polymerization. Polym. J. 43, 105-120 (2010).

11 Ouchi, M., Terashima, T. \& Sawamoto, M. Precision control of radical polymerization via transition metal catalysis: from dormant species to designed catalysts for precision functional polymers. Accounts. Chem. Res. 41, 1120-1132 (2008).

12 Matyjaszewski, K. \& Xia, J. H. Atom transfer radical polymerization. Chem. Rev. 101, 2921-2990 (2001).

13 Tsarevsky, N. V. \& Matyjaszewski, K. 'Green' atom transfer radical polymerization: from process design to preparation of well-defined environmentally friendly polymeric materials. Chem. Rev. 107, 2270-2299 (2007).

14 Rosen, B. M. \& Percec, V. Single-electron transfer and single-electron transfer degenerative chain transfer living radical polymerization. Chem. Rev. 109, 5069-5119 (2009).

15 Oh, J. K., Perineau, F., Charleux, B. \& Matyjaszewski, K. AGET ATRP in water and inverse mini emulsion: a facile route for preparation of high-molecular-weight biocompatible brush-like polymers. J. Polym. Sci. Pol. Chem. 47, 1771-1781 (2009).

16 Coca, S., Jasieczek, C. B., Beers, K. L. \& Matyjaszewski, K. Polymerization of acrylates by atom transfer radical polymerization. Homopolymerization of 2-hydroxyethyl acrylate. J. Polym. Sci. Pol. Chem. 36, 1417-1424 (1998).

17 Ashford, E. J., Naldi, V., O'Dell, R., Billingham, N. C. \& Armes, S. P. First example of the atom transfer radical polymerisation of an acidic monomer: direct synthesis of methacrylic acid copolymers in aqueous media. Chem. Commun. 1285-1286 (1999).

18 Wang, X. S., Jackson, R. A. \& Armes, S. P. Facile synthesis of acidic copolymers via atom transfer radical polymerization in aqueous media at ambient temperature. Macromolecules 33, 255-257 (2000).

19 Wang, X. S. \& Armes, S. P. Facile atom transfer radical polymerization of methoxycapped oligo(ethylene glycol) methacrylate in aqueous media at ambient temperature. Macromolecules 33, 6640-6647 (2000).

20 Lobb, E. J., Ma, I., Billingham, N. C., Armes, S. P. \& Lewis, A. L. Facile synthesis of well-defined, biocompatible phosphorylcholine-based methacrylate copolymers via atom transfer radical polymerization at 20 degrees C. J. Am. Chem. Soc. 123, 7913-7914 (2001).

21 Yoda, H., Nakatani, K., Terashima, T., Ouchi, M. \& Sawamoto, M. Ethanol-mediated living radical homo- and copolymerizations with $\mathrm{Cp}^{*}$-Ruthenium catalysts: active, robust, and universal for functionalized methacrylates. Macromolecules 43, 5595-5601 (2010).

22 Daigle, D. J., Pepperma, A. B. \& Vail, S. L. Synthesis of a monophosphorus analog of hexamethylenetetramine. J. Heterocyclic Chem. 11, 407-408 (1974).

23 Fagan, P. J., Ward, M. D. \& Calabrese, J. C. Molecular engineering of solid-state materials - organometallic building-blocks. J. Am. Chem. Soc. 111, 1698-1719 (1989).

24 Ando, T., Kamigaito, M. \& Sawamoto, M. Silyl enol ethers: end-capping agents for living radical polymerization of methyl methacrylate with ruthenium complex. Macromolecules 31, 6708-6711 (1998).

25 Robinson, K. L., Khan, M. A., Banez, M. V. D., Wang, X. S. \& Armes, S. P. Controlled polymerization of 2-hydroxyethyl methacrylate by ATRP at ambient temperature. Macromolecules 34, 3155-3158 (2001).

26 Beers, K. L., Boo, S., Gaynor, S. G. \& Matyjaszewski, K. Atom transfer radical polymerization of 2-hydroxyethyl methacrylate. Macromolecules 32, 5772-5776 (1999).

27 Fuji, Y., Watanabe, K., Baek, K.- Y., Ando, T., Kamigaito, M. \& Sawamoto, M. Controlled radical polymerization of 2-hydroxyethyl methacrylate with a hydrophilic ruthenium complex and the synthesis of amphiphilic random and block copolymers with methyl methacrylate. J. Polym. Sci. Pol. Chem. 40, 2055-2065 (2002).

Supplementary Information accompanies the paper on Polymer Journal website (http://www.nature.com/pj) 